\title{
GEOTECHNICAL ASPECTS OF THE 2007 NIIGATAKEN CHUETSU-OKI, JAPAN EARTHQUAKE
}

\author{
Rolando P. Orense ${ }^{1}$, Masayuki Hyodo ${ }^{2}$, Hiroaki Kanda ${ }^{3}$ and \\ Junya Ohashi ${ }^{3}$
}

\begin{abstract}
SUMMARY
On 16 July 2007, an earthquake of magnitude 6.8 occurred with an epicentre off the west coast of Niigata Prefecture (Japan), causing widespread damage to buildings and other types of civil engineering structures due to ground shaking and earthquake-induced ground failures. Landsliding and soil liquefaction occurred extensively in various parts of the affected region. This paper presents the preliminary results of the post-earthquake damage investigation conducted at the affected areas after the earthquake, with emphasis on the seismic-induced ground failures and their effects on the built environment.
\end{abstract}

\section{INTRODUCTION}

A large earthquake, with magnitude $M_{J M A}=6.8\left(M_{w}=6.6\right)$ occurred at 10:13 AM on 16 July 2007 off the coast of Chuetsu Region, Niigata Prefecture (Japan). The earthquake, with focal depth of $17 \mathrm{~km}$, had an epicentre located offshore, about $60 \mathrm{~km}$ southwest of Niigata City. The earthquake registered a Japan Meteorological Agency (JMA) seismic intensity of 6+ (about IX in MMI scale) in Kariwa Village, Kashiwazaki City and Nagaoka City (all in Niigata Prefecture) and in Ohzuna Town (Nagano Prefecture). A seismic intensity of 6- was also registered in three other areas (see Figure 1). At about 3:37 PM of the same day, a large aftershock, with magnitude $M_{J M A}=5.6$, also occurred with focal depth of 10 $\mathrm{km}$.

As a result of the quake, 15 people were killed and 2,315 people were injured. In addition, 1,319 houses in Niigata Prefecture totally collapsed while another 857 houses suffered extensive damage (Niigata Prefecture, 2007). Major lifelines, such as gas, water and electricity, were affected and suspended for more than one day in several areas. In Kariwa Village, a large nuclear power plant was reportedly damaged due to the large ground shaking (TEPCO, 2007). More than fifty cases of landslides and other slope failures were reported, and liquefaction was observed in several areas near the coasts.

Although the earthquake-induced ground failures were extensive, the damage induced was not catastrophic. This was because the affected area was not densely populated with few commercial and business establishments. If this had happened in populated business centres such as in Tokyo, extensive damage to both life and property would have occurred.
It is worthy to mention that Typhoon No. 4 (international name: Man-Yi) and a seasonal rain front passed the region a day before the earthquake. Although the typhoon had lost most of its intensity as it traversed the country from the south to the Pacific coast, it still dumped large amount of rainfall in the prefecture which may have saturated most of the slopes and contributed to the extent and magnitude of the slope failure observed in the area..

This paper gives a brief summary of the post-earthquake investigation results performed in the area a week after the disaster. Emphasis is placed on the geotechnical features of the earthquake, highlighting the ground damage observed in Kashiwazaki City and neighbouring areas.

\section{GEOLOGY AND TOPOGRAPHY}

The topography of the Chuetsu Region is characterized by rivers and ridges of hill extending from north-northeast to south-southwest (Uemura and Yamada, 1998). This region is well-known to be one of major landslide areas in Japan. Sedimentary rocks after the Neocene are distributed thickly. They are classified as "soft rocks" and are intercalated by unconsolidated mudstone and tuff layers, making them susceptible to earthquake-induced landslides.

Kashiwazaki City is located in a flat river valley at the centre of the coastline in Niigata Prefecture and in the Kariwa Plain. The city is surrounded by mountains and spreads over a set of sand dunes, which has been elongated along the coast in such a way that the mouths of both Ugawa River and Sabaishigawa River (two major rivers flowing into Japan Sea) are bent southwest. Sand, silt, mud and other suspended matter that have been carried by these two rivers over centuries have been

\footnotetext{
${ }^{1}$ Senior Lecturer, Department of Civil and Environmental Engineering, University of Auckland, New Zealand (member)

${ }^{2}$ Professor, Department of Civil Engineering, Yamaguchi University, Ube, Japan

${ }^{3}$ Graduate Student, Department of Civil Engineering, Yamaguchi University, Ube, Japan
} 

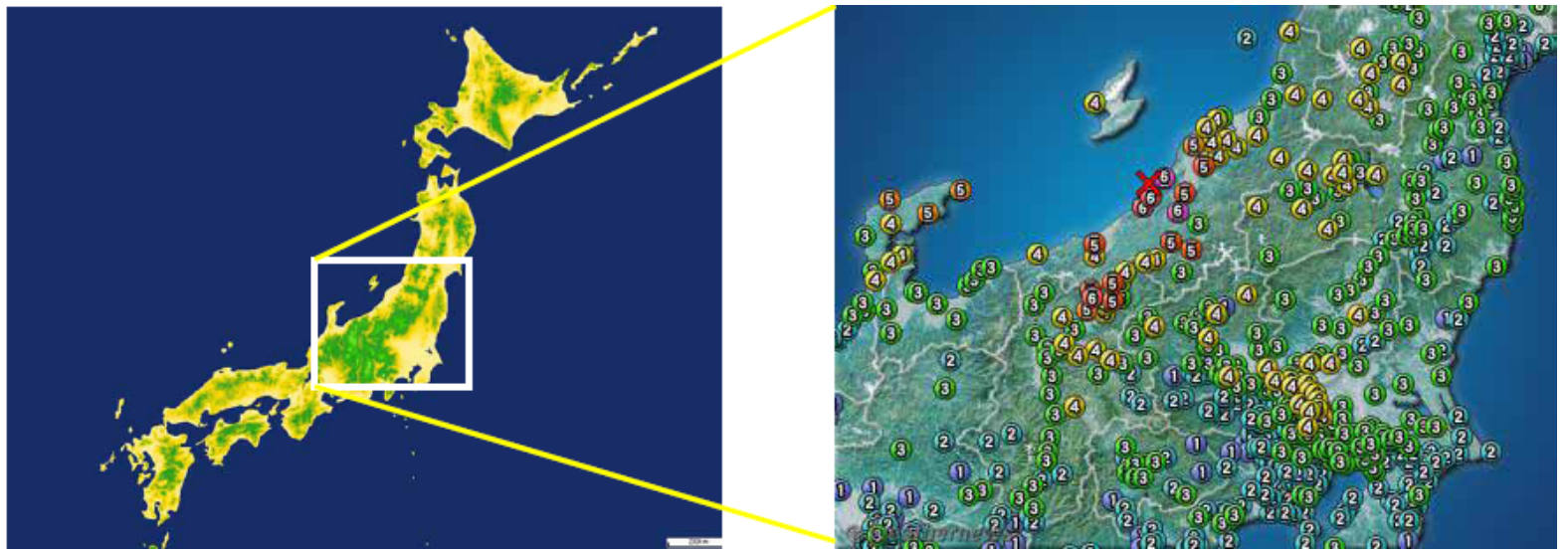

Figure 1: Location of earthquake epicentre and distribution of seismic intensities (data from NIED)

deposited southeast behind the sand dunes. The urban areas of Kashiwazaki City were built over these soft alluvial deposits.

\section{RECENT EARTHQUAKE HISTORY}

The Chuetsu region of Niigata Prefecture has been affected by recent major earthquakes. On 25 March 2007, a magnitude $M_{J M A}=6.9$ earthquake struck offshore of Noto Peninsula, Ishikawa Prefecture, located about $180 \mathrm{~km}$ southwest of the prefecture. The earthquake, with focal depth of $11 \mathrm{~km}$, resulted in 1 death, 297 injured and caused failures of several highway embankments. On 23 October 2004, a $M_{w}=6.6$ earthquake occurred with epicentre about $30 \mathrm{~km}$ southsoutheast of the present one. The earthquake, officially called the 2004 Niigataken Chuetsu Earthquake, caused a large number of landslides in the mountainous region near the epicentre and forced local authorities to suspend operation in 233 segments of national and prefectural routes.

The Niigata Prefecture will always be associated with the widespread liquefaction of the alluvial deposits induced by the 1964 Niigata Earthquake. The earthquake, which struck on 23 October 1964, had an epicentre $115 \mathrm{~km}$ north-northeast of this recent earthquake and resulted in 23 deaths and destruction of the major portions of the city due to liquefaction-induced ground deformations.

\section{STRONG MOTION RECORDS}

The 2007 earthquake triggered many strong motion recorders installed throughout the affected area. Figure 2 shows the records obtained by K-Net in Kashiwazaki City, where a JMA seismic intensity of $6+$ was recorded. Note that K-Net is operated by the National Research Institute for Earth Science and Disaster Prevention (NIED). It can be observed from the records that the horizontal components show spiky response, which is typically observed in dense sands undergoing a state of cyclic mobility due to liquefaction. Peak accelerations are observed in the time period between 25-28 sec when the spikes are predominant. The maximum values recorded in this

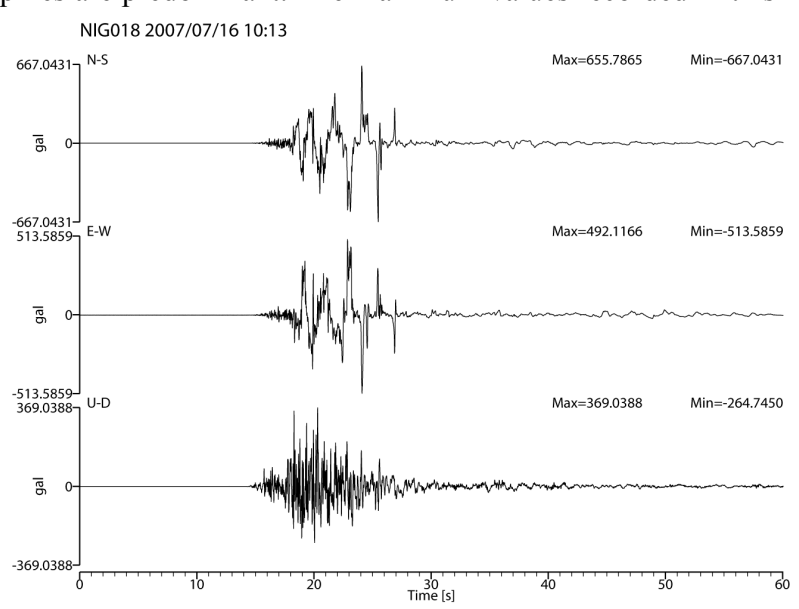

Figure 2: K-Net strong motion records at Kashiwazaki City (data from K-Net).

site were 667,514 and $369 \mathrm{~cm} / \mathrm{sec}^{2}$ in the NS, EW and UD directions, respectively. The duration of shaking lasted for about $10 \mathrm{sec}$. A check on the soil profile at the site revealed dense sandy soil (SPT $N$-value $>20$ ) between GL-3m to $-13 \mathrm{~m}$.

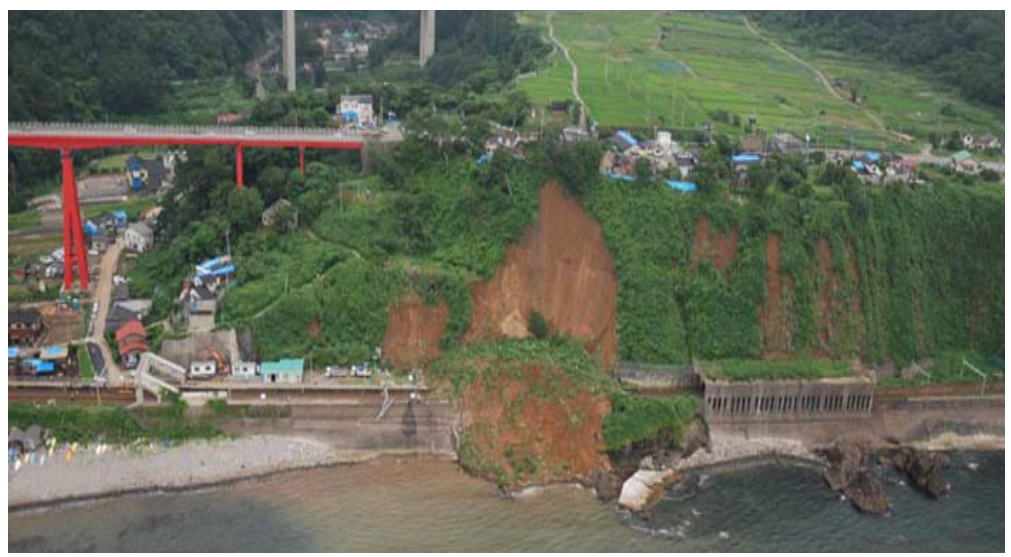

Figure 3: Slope failure near JR Omigawa station (photo by Kokusai Kogyo Co. Ltd). 
Table 1: Comparison of peak ground accelerations recorded during this earthquake and other recent earthquakes in Japan.

\begin{tabular}{|c|c|c|c|c|}
\hline \multirow{2}{*}{ Earthquake } & \multirow{2}{*}{ Seismic Station } & \multicolumn{3}{|c|}{ Maximum Acceleration $\left(\mathrm{cm} / \mathrm{sec}^{2}\right)$} \\
\hline & & $\mathbf{N}-\mathbf{S}$ & E-W & U-D \\
\hline \multirow{2}{*}{$\begin{array}{l}2007 \text { Niigataken Chuetsu oki } \\
\text { Earthquake }\end{array}$} & K-Net Kashiwazaki & 667 & 514 & 369 \\
\hline & K-Net Ojiya & 391 & 455 & 116 \\
\hline \multirow{2}{*}{2007 Noto Hanto oki Earthquake } & K-Net Anamizu & 473 & 782 & 556 \\
\hline & K-Net Togi & 717 & 849 & 462 \\
\hline \multirow{2}{*}{2004 Niigataken Chuetsu Earthquake } & JMA Kawaguchi & 1142 & 1676 & 870 \\
\hline & K-Net Ojiya & 1144 & 1308 & 820 \\
\hline 2003 Tokachi Oki Earthquake & K-Net Hiroo & 810 & 970 & 461 \\
\hline \multirow{2}{*}{1995 Hyogoken Nambu Earthquake } & Kobe Marine Observatory & 818 & 617 & 332 \\
\hline & JR Tottori Station & 608 & 645 & 280 \\
\hline
\end{tabular}

Near the station, large cracks were observed on the asphalt roads, indicating the occurrence of lateral spreading in the downslope direction.

Table 1 compares the maximum peak ground accelerations (PGA) recorded during this earthquake and those registered
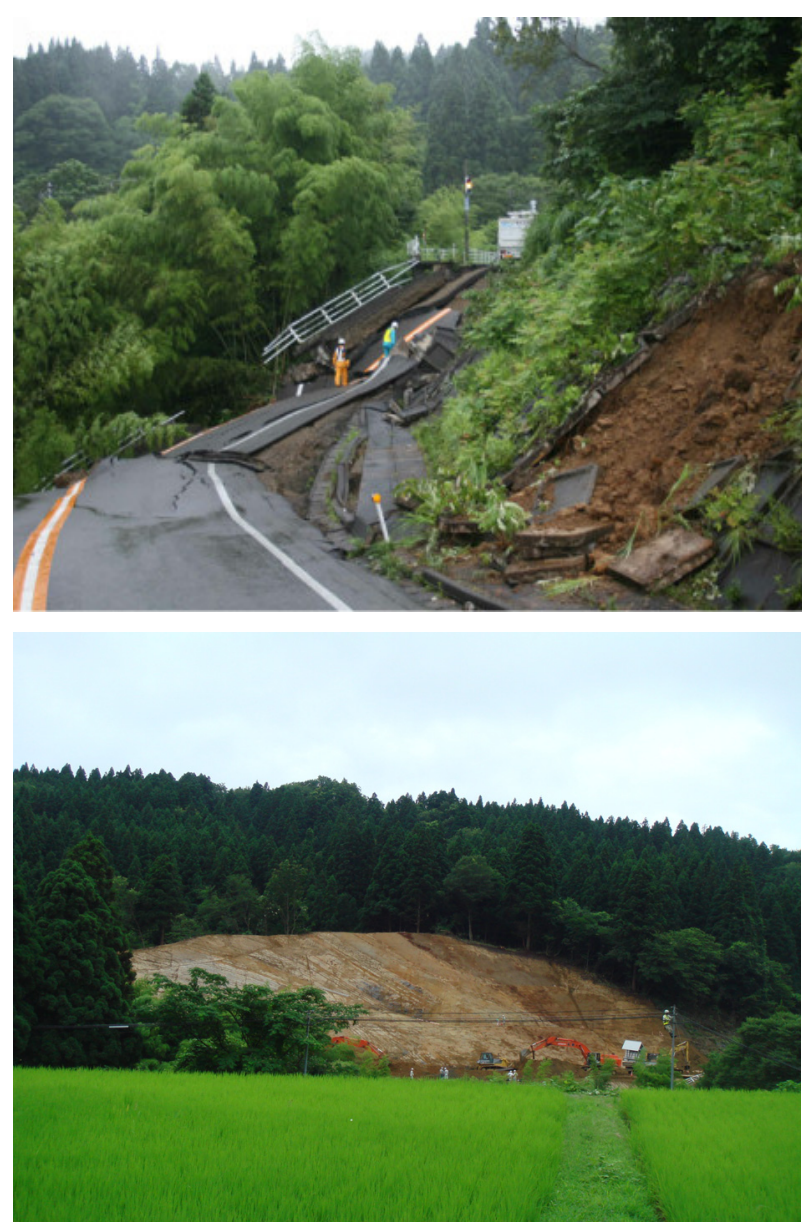

Figure 4: Top photo shows the slope failure along National Route No. 8 in Senbon, Nagaoka City (photo by Prof. Inoue). Bottom photo shows the reconstruction works during the site visit. during other recent earthquakes in Japan. It can be observed that with the exception of those recorded during the 2004 Niigataken Chuetsu Earthquake, the PGAs during this earthquake are remarkably of the same level as those observed in other recent large-scale earthquakes.
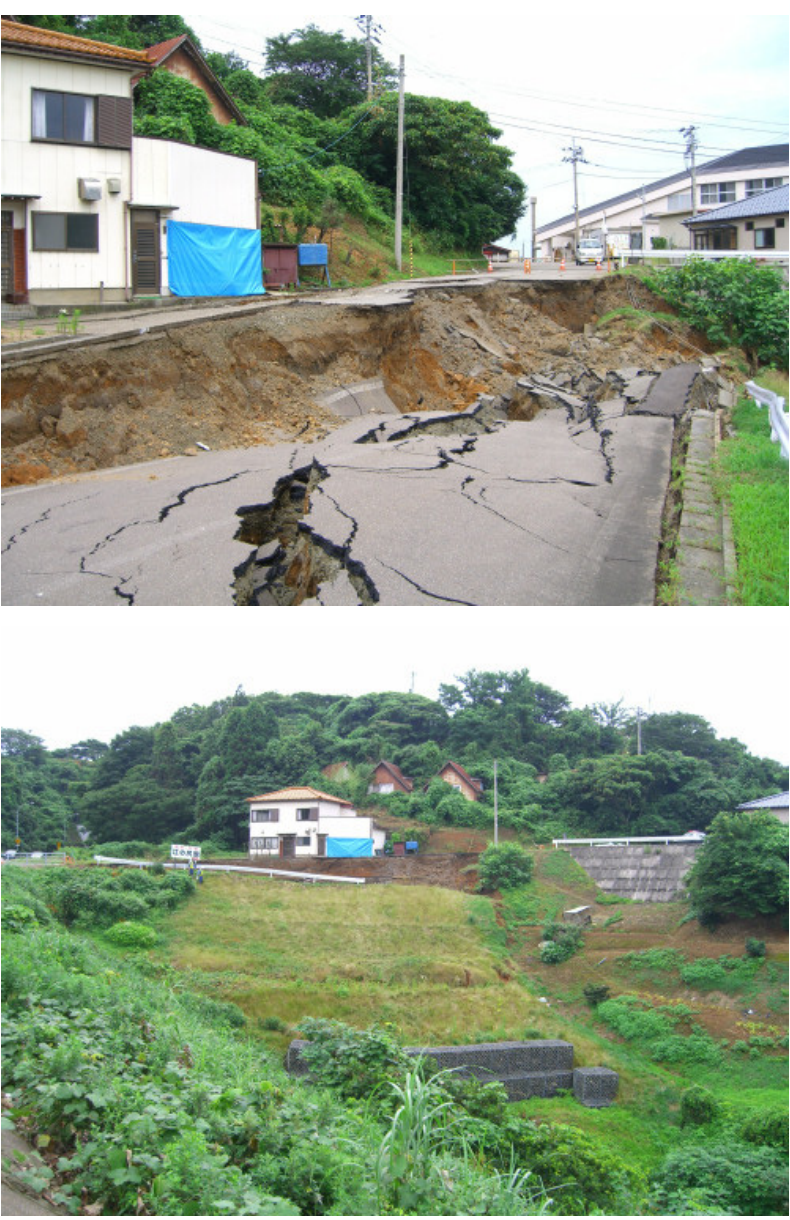

Figure 5: Top photo illustrates the collapse of man-made embankment in Kasashima. Bottom photo shows the slope stabilization measures applied at the site. 


\section{GROUND FAILURES CAUSED BY THE EARTHQUAKE}

\section{Slope failures}

The slope failures caused by this earthquake consisted of shallow translational slides, debris slumps and deep-seated rotational slides. Although Typhoon No. 4 passed through the area a few days before the earthquake, the soils were generally not wet enough to induce debris flows; however, the resulting saturation of the slopes may have intensified the damage.

One major landslide occurred in the vicinity of JR Shin-etsu Mainline's Omigawa station (see Figure 3) where the debris covered part of the railway line. Fortunately, no one was injured due to the landslide. The slope was fairly steep and the slide involved a volume of soil about $100 \mathrm{~m}$ high, $50 \mathrm{~m}$ wide and $10 \mathrm{~m}$ deep. The resulting scar had an almost vertical face. Because of the steep hills in the vicinity of the station, other landslides were observed in the area as well. Note from the figure the presence of railway tunnel protection structure immediately to the right of the landslide, indicating slope instability problems in the area.

Another large-scale landslide occurred along National Route No. 8, which connects Kashiwazaki to Nagaoka. The landslide, which occurred in the foothills of Senbon (east of Kashiwazaki), started at about $60 \mathrm{~m}$ above the road pavement (see Figure 4). The slide pushed the highway into the Kurokawa River which runs parallel to the road (on the left lower portion of the photo). The debris covered about $80 \mathrm{~m}$ section of the road, causing the suspension of traffic operation along this major road.
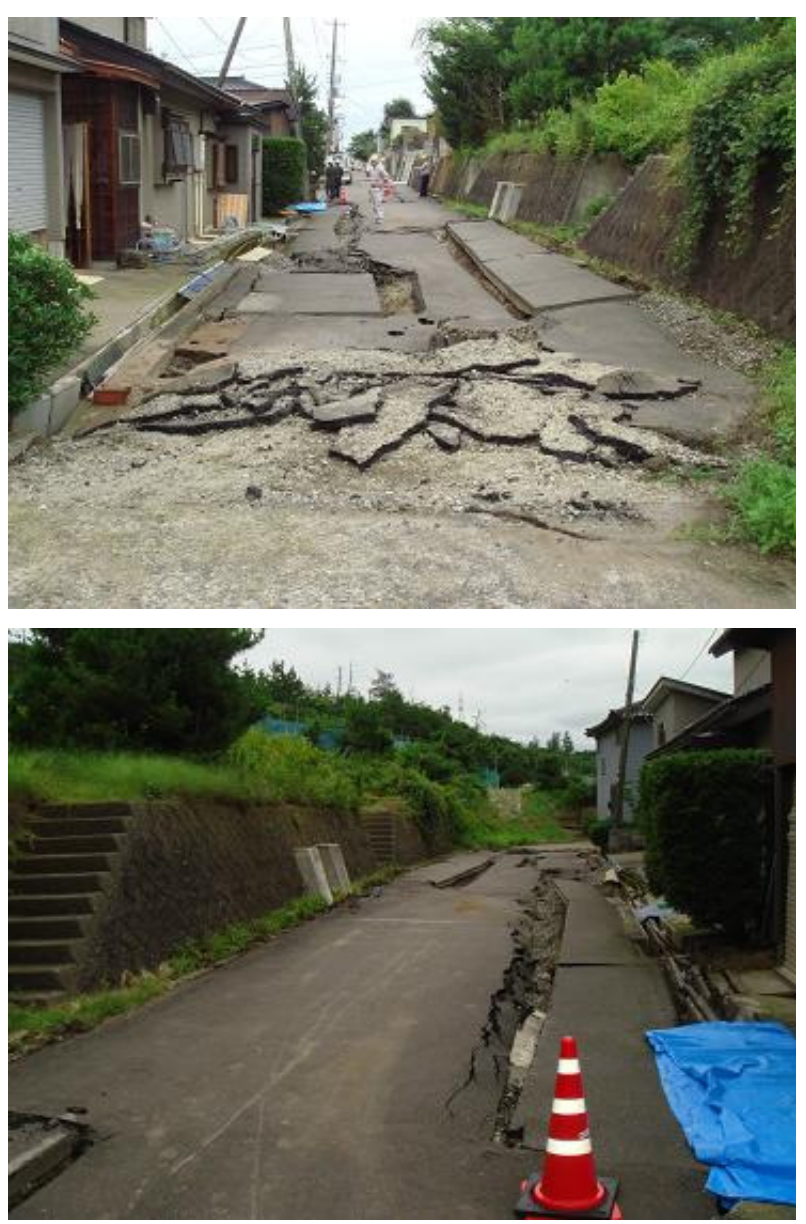

Figure 7: Liquefaction-induced ground deformations in Yamamoto Danchi, Yamamoto town.
Several embankment failures were observed in road fills along the coast. In Kasashima off Route No. 8, a 60 m-portion of an embankment underwent more than $1 \mathrm{~m}$ of vertical displacement, resulting in road closure (see Figure 5). In the vicinity of this area, sand boils and ground fissures were observed, indicating the possibility of liquefaction-induced slope failure. The slope appeared to have undergone previous stabilization using slope grading and gabion baskets to support the toe, as shown by the lower photo in the figure.

\section{Soil liquefaction}

As mentioned earlier, the urban area of Kashiwazaki City is sitting on land containing alluvial soils where the sand deposits have flowed from the rivers over the soft alluvial formation. These soil profiles are very susceptible to liquefaction, as evidenced by the observed sand boils and ground fissures in many locations in Kashiwazaki City and Kariwa Village, particularly in riverbank deposits, beach deposits, dune sands and placed fills. Some of the major liquefied sites are described below.

The road parallel to the Sabaishi River which leads to the Kashiwazaki City's Garbage Incinerator Plant underwent extensive liquefaction. The road spread laterally towards the river, resulting in massive embankment failure (See Figure 6). The vertical displacement of the head scarp was about $3 \mathrm{~m}$ (maximum), with the lateral spread movement occurring from the sand quarry area towards the river. Sand boils were also observed near the river. Based on the locations of sand boils and ground cracks, it was inferred that this site may have been a former river channel of the Sabaishi River which was buried when the road was constructed.
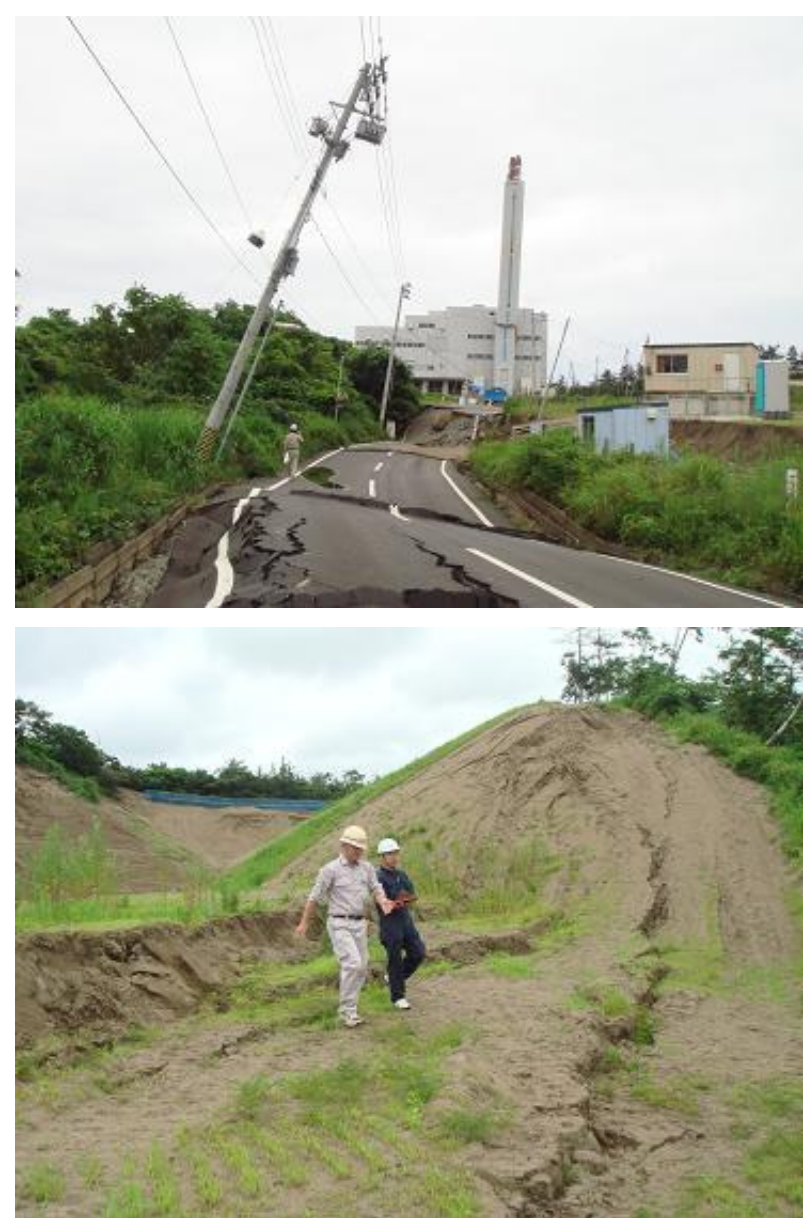

Figure 6: Top photo: liquefaction-induced collapse of the road leading to Kashiwazaki Incinerator Plant; Bottom photo: quarry site immediately to the right of the road. 

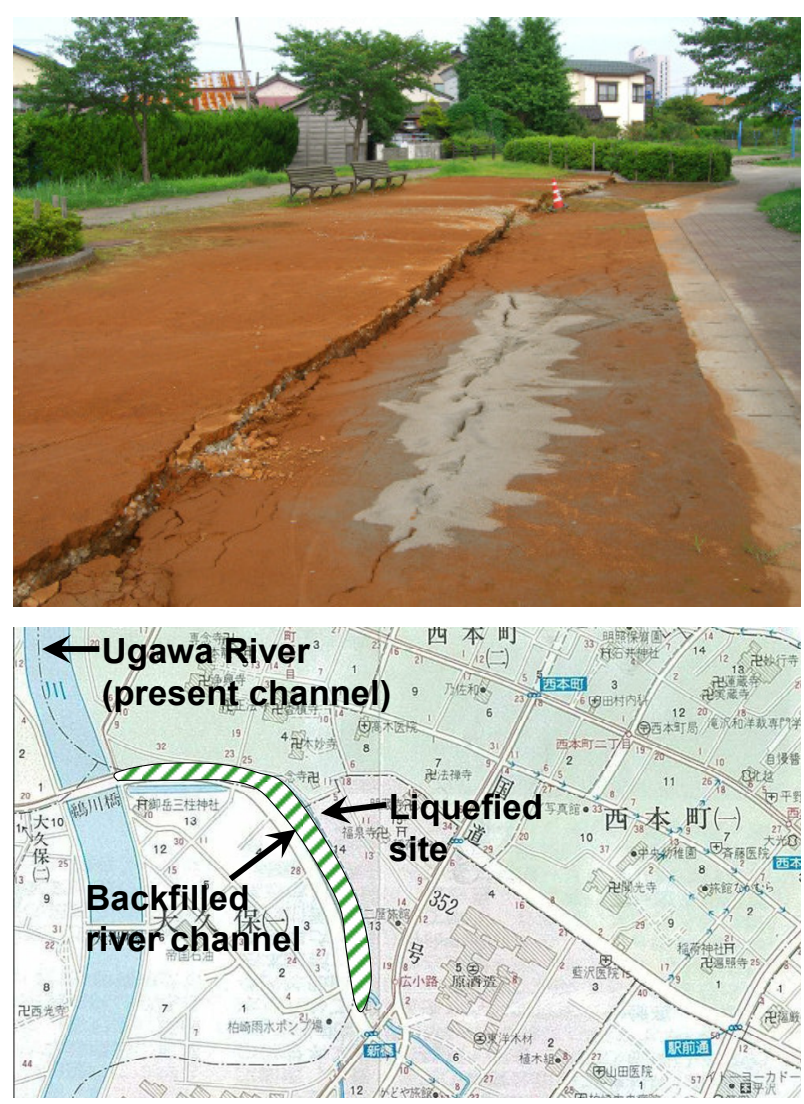

Figure 8: Top photo: Ground crack and sand boils induced by soil liquefaction at Suidobashi Park; Bottom map: location of backfilled river channel and liquefaction site.

Also seen in the background of the top photo is the damaged exhaust chimney of the plant. The reinforced concrete chimney, measuring $60 \mathrm{~m}$ high by $4.5 \mathrm{~m}$ wide, was broken at the lapped splice of the longitudinal reinforcements slightly below the centre of the chimney.

Another area of considerable damage was observed in Yamamoto Danchi, Yamamoto Town adjacent to the incinerator plant (Figure 7). Cracked pavements, uplifted manholes, lateral spreading and uneven settlements were observed in many parts of the area. Although these observed ground deformations were localized in nature, they resulted in extensive damage to residential houses, road facilities and water supply networks.

Extensive liquefaction was also observed at the Suidobashi Park in Nishimoto, Kashiwazaki City. A very long ground crack was observed traversing through the entire length of the park (Figure 8). Relative settlements ranging from a few centimetres to as much as $200 \mathrm{~mm}$ accompanied the ground crack. Sand boils and ground fissures were also seen adjacent to this crack. Further investigation showed that the region which settled was a former river channel backfilled with soil at the time the Ugawa River system was straightened in 1997. During this time, flood mitigation efforts were implemented and the area was transformed into a park.

Sand boils, cracks and large ground fissures were also observed at various locations in Sabaishigawa Memorial Park in Makihara, Kashiwazaki City (Figure 9). The park was constructed on a sandbar formed by two branches of the Sabaishi River. As part of the river improvement schemes implemented in the 1990s, the river was straightened by backfilling the northern branch. Apparently, the old river channel and portions of the sand bar liquefied during this earthquake, causing lateral spreading towards the existing river channel.
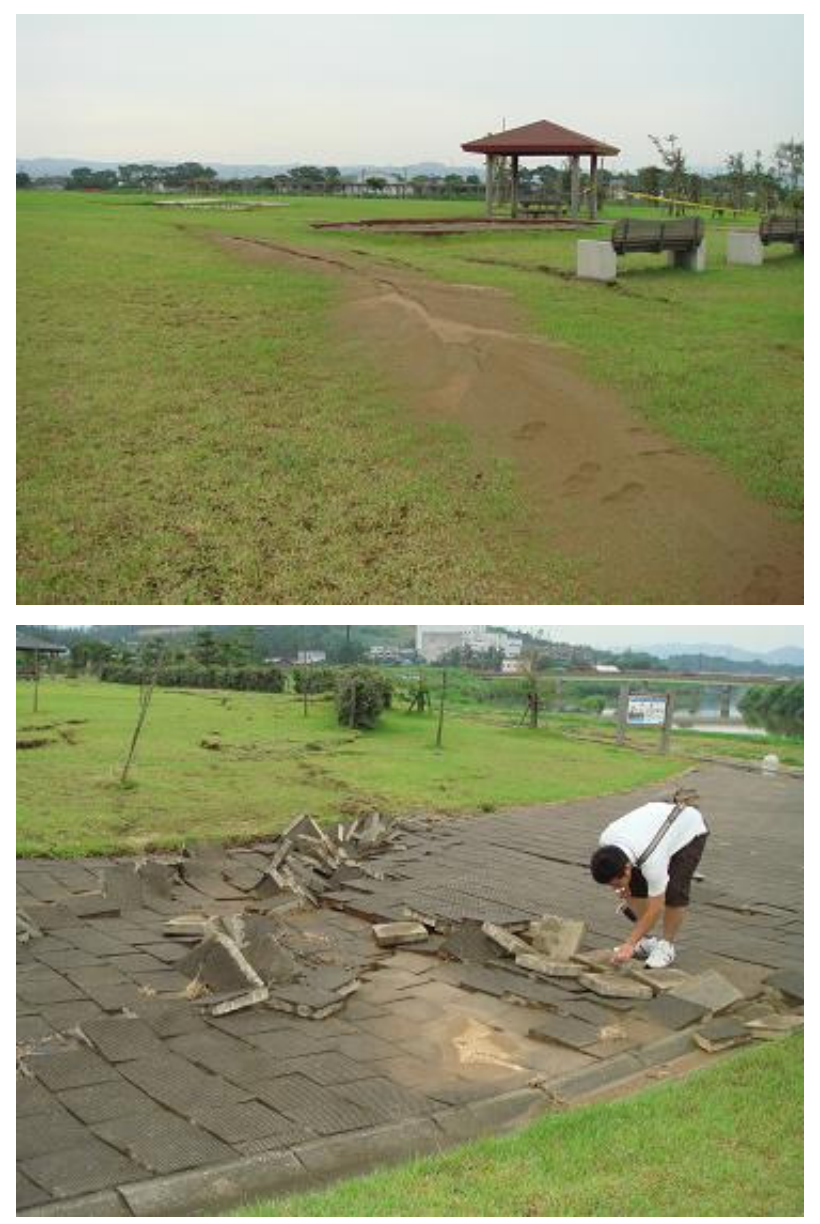

Figure 9: Sand boils and ground fissure observed in Sabaishigawa Memorial Park.

\section{DAMAGE TO OTHER CIVIL ENGINEERING STRUCTURES}

\section{Port, harbour and coastal structures}

The earthquake affected several coastal structures in Niigata Prefecture. Among these, the Kashiwazaki Port, the largest facility in the affected region with approximately $1.25 \mathrm{~km}$ of waterfront berths, suffered extensive damage due to liquefaction-induced ground deformations. At the West Wharf, settlement and displacement of the quay walls opened joints in the aprons and deformed the ground in the yard area (see top photo in Figure 10). At the Fishing Port, the apron settled by as much as $200 \mathrm{~mm}$ due to the lateral displacement of the quay wall toward the sea (see bottom photo in Figure 10). Similar types of damage were observed at the Central Wharf, where cracked pavements, deformed quay walls and uneven surfaces were noted. In addition, the boiled sands and fissures caused by liquefaction were observed in many places around the harbour.

The Eastern Berth, which was being used by the Japan Coast Guard and Japan Self-Defence Forces as a staging area for recovery and rebuilding efforts, suffered minor liquefaction effects, with lateral displacements in the order of $<50 \mathrm{~mm}$ and apron settlements ranging from $20-70 \mathrm{~mm}$.

The Kashiwazaki Aquapark building, located near the port, suffered damage as a result of ground shaking and liquefaction of the foundation soil. The majority of the perimeter of the main building settled and lateral separation between an external wall and the main building occurred (see Figure 11). Although details of the type of building foundation was not available at the time of the visit, it was inferred that the main 

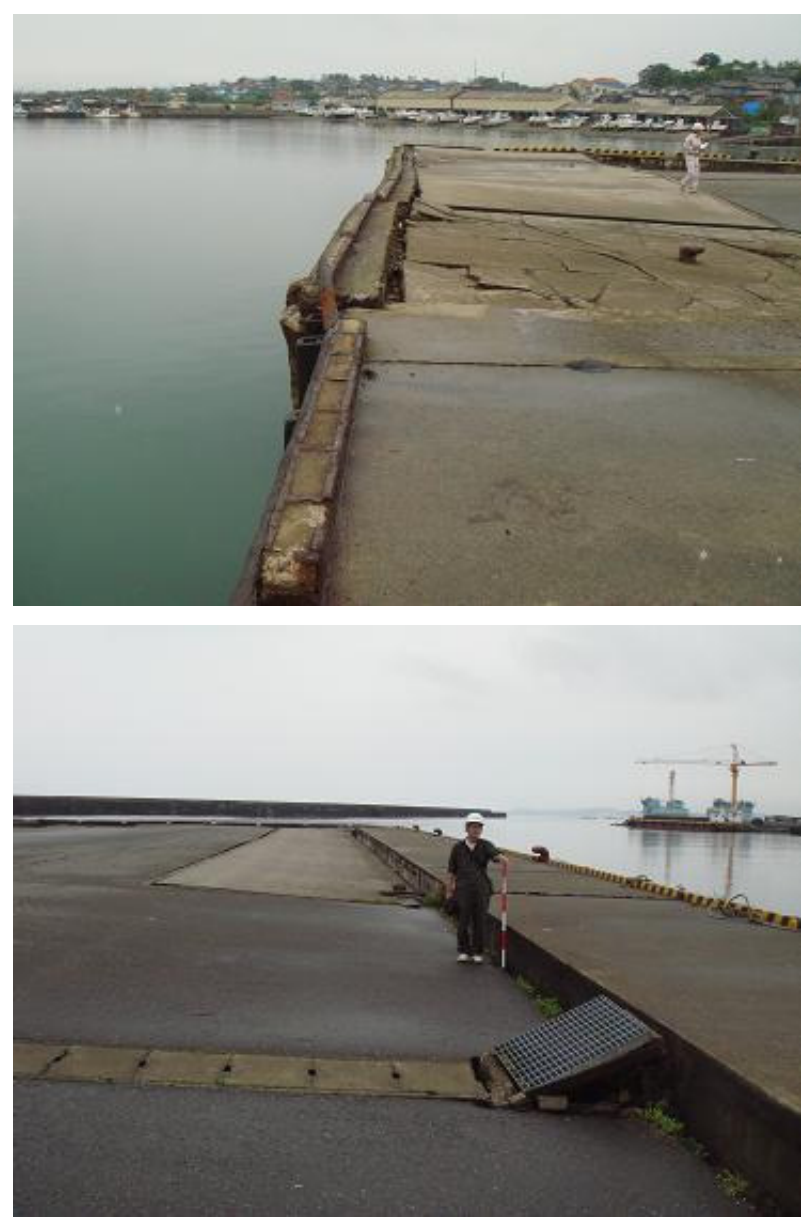

Figure 10: Damage to Kashiwazaki Port. Top photo shows lateral spreading of the quay wall towards the sea while bottom photo shows settlement of the apron.

structure was supported by pile foundations, and the liquefaction of the foundation ground caused uneven ground settlement with no major effect on the main structure.

\section{Railway facilities}

Damage to railway lines were also evident in the region, although highly localized. Between Arahama Station and Nishiyama Station on the JR Echigo Line, the rail track buckled at locations where the railway embankment moved laterally during the earthquake (top photo of Figure 12). Moreover, the Arahama Station platform was completely damaged, together with the powerlines and signalling equipment, as a result of liquefaction-induced settlement and lateral spreading (bottom photo of Figure 12).

\section{PROPERTIES OF EJECTED SANDS}

As mentioned earlier, sand boils were observed in various sites such as in riverbank deposits, beach deposits, dune sands and placed fills. Samples were obtained at three sites in Kashiwazaki City, namely in Yamamoto Danchi (Figure 7), Suidobashi Park (Figure 8) and Sabaishigawa Memorial Park (Figure 9) and the corresponding grain size distribution curves are shown in Figure 13. Although it can be observed that the sand boils in Suidobashi Park were much coarser than those in Sabaishigawa Memorial Park, all the grain sizes fit the range proposed by Tsuchida (1971) for materials with a high possibility of liquefaction.
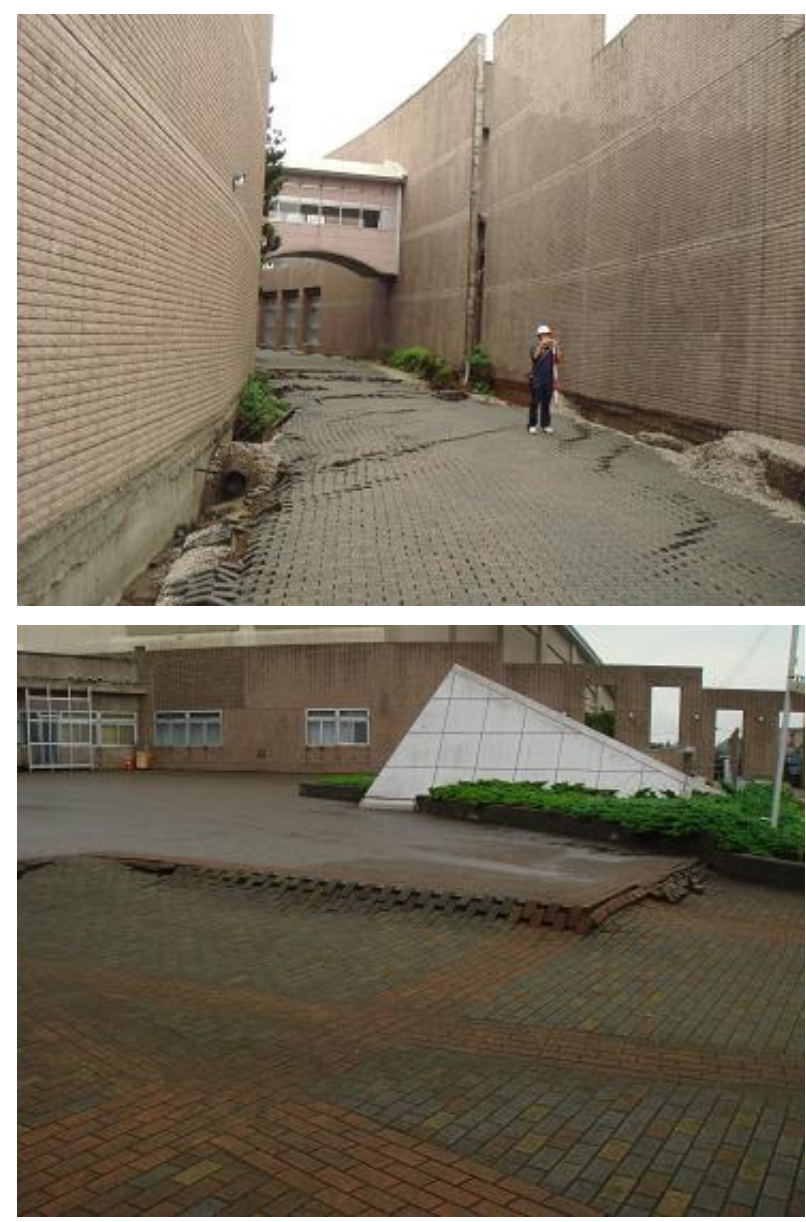

Figure 11: Damage to Kashiwazaki Aquapark. Top photo shows uneven settlements in the perimeter of the building and lateral separation of the walls; bottom photo shows the settlement of the pavement in front of the building.

\section{CONCLUDING REMARKS}

Although considered not as catastrophic, extensive ground failures, such as landsliding and liquefaction-induced ground deformations, occurred as a results of the earthquake. Due to its geologic and topographic nature, liquefaction and slope failures were the main causes of damage observed in Kashiwazaki City. Lateral spreading and uneven ground settlements caused damage to port and railway structures and the amplified ground motion in the liquefied area caused serious damage to buildings. The typhoon that passed through the affected site days before the earthquake may have compounded the damage since the saturated ground resulted in numerous landslides.

\section{ACKNOWLEDGMENTS}

The authors would like to acknowledge the assistance of Dr. Y. Yamamoto of Sumitomo Mitsui Construction Co. Ltd. and Dr. Y. Fujii of Fukken Co. Ltd. for the assistance in conducting the reconnaissance visit to the site. The strong motion record in Kashiwazaki was obtained from K-net operated by NIED while the peak ground accelerations were taken from the strong motion records of Japan Meteorological Agency (JMA) and K-Net. 

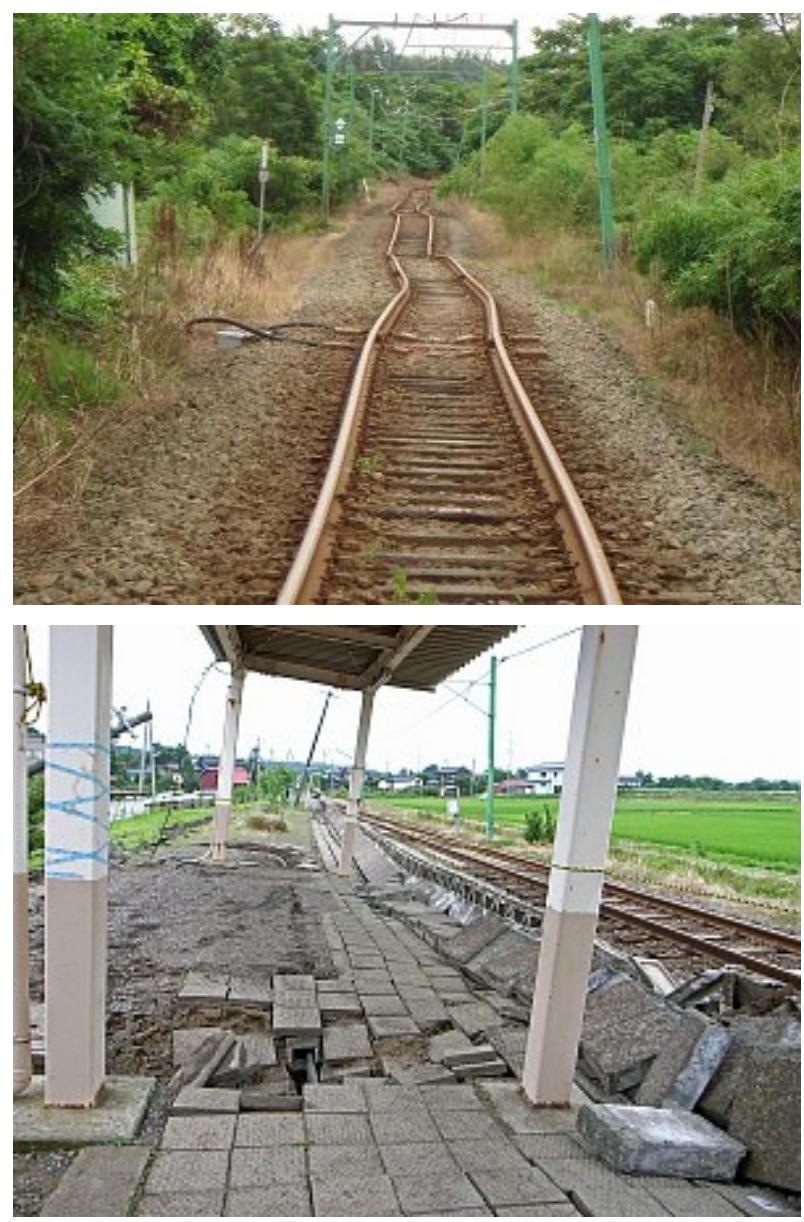

Figure 12: Damage to railway facilities: top photo shows the buckled railway track while the bottom photo shows the damaged platform of Arahama train station.

\section{REFERENCES}

1 Niigata Prefecture (2007) "Damage condition caused by the 16 July 2007 Nigataken Chuetsu oki Earthquake (as of 14 December 2007)" Report No. 212 (in Japanese).

2 Tokyo Electric Power Company, TEPCO (2007) "Plant status of Kashiwazaki-Kariwa Nuclear Power Station after the Niigata Chuetsu oki-Earthquake”. 24 July 2007 Press Release.

3 Tsuchida, H. (1971) "Estimation of liquefaction potential of sandy soils". Proceedings, 3rd joint meeting, USJapan Panel on Wind and Seismic Effects, UJNR.

4 Uemura, T. and Yamada, T. (1998) Geology in Japan, 4. Central Japan Part I, Kyoritsu Shuppan (in Japanese).

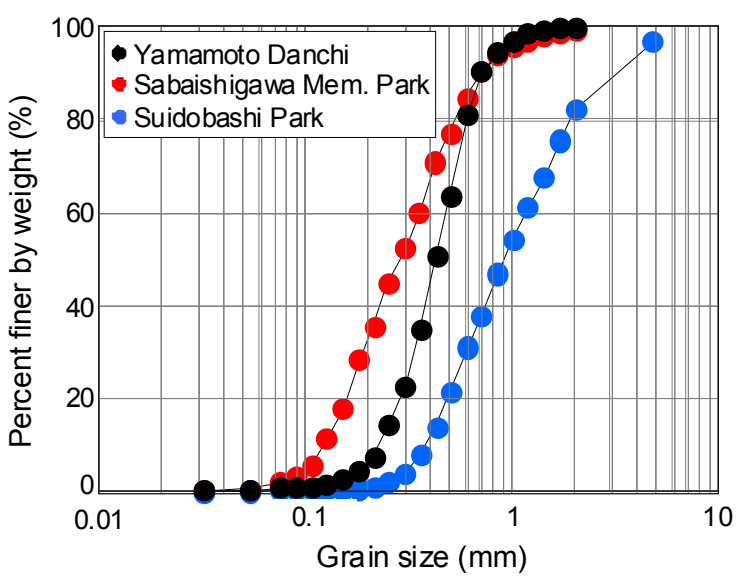

Figure 13: Grain size distribution curves of eiected sands 